\title{
Performance Evaluation of Adama City Water Supply System, Oromia, Ethiopia
}

\author{
Ismail Fekrudin* \\ Lecturer, Dept. Hydraulics and water resource engineering, Dilla University, Dilla Ethiopia, \\ P.O.Box: 419; Dilla, Ethiopia
}

Sisay Demeku $(\mathrm{PhD})$

Lecturer, Dept. of Civil engineering. Addis Ababa Science and Technology University, Addis Ababa Ethiopia, P.O.Box: 16417; Addis Ababa, Ethiopia

\begin{abstract}
This study was to evaluate the performance of Adama city water supply system and to recommend the improvement measures for the water supply system. Performance evaluation of the water supply system, user perception, Percapita water consumption, and water loss was analyzed. Among the International Water association Indicators(IWA) of water supply service, water resource indicator shows better performance, from quality of service indicators, average water tariff performance was better but need improvement, water resource indicators result shows better performance, from personnel indicators employees per connection, and operation and maintenance personnel shows poor performance, and from physical indicators treated water storage shows better performance, metered customer good, and microbiological and chemical test carried out shows poor performance. Households included in the analysis which connected to the water distribution network were $72 \%$. Out of the total households included in the study, of the total respondents, $67 \%$ have individual connection $20.33 \%$ use community tap and $12.67 \%$ buy water from vendors. From the total households in the town, about $35 \%$ were collect rainwater. The average per capita consumption of Adama city was $38.251 / \mathrm{c} / \mathrm{d}$ and the water loss was $34.67 \%$ of the system input volume.
\end{abstract}

Keywords: Adama City, Performance evaluation, Performance indicator, User perception, Water loss.

DOI: $10.7176 / \mathrm{CER} / 11-9-04$

Publication date:October $31^{\text {st }} 2019$

\section{Introduction}

The reliable supply of safe and good quality water is the primary objective of any water supply utility. The performance of a water supply and sanitation (WSS) was assessed by selecting suitable performance indicators (PIs). The general concept of evaluating the performance of a WSS is to compare its performance with established benchmarks through cross-comparison with similar utilities (Alegre et al. 2000).

The existing water supply system of Adama city does not satisfy the water requirement of the tremendously increasing population of the city, large industrial development and a complaint regarding service provision from customer side. So that, there is a need to investigate the performance situation of the water supply system of the city. Therefore, this research was conducted to assess the performance of the existing water supply system of the city, water resource and financial, physical and operational, quality of service and personnel were carried out using performance indicators suggested by IWA, the user perception, Percapita water consumption and water loss were analyzed and possible measurement which used to improve the current situation of the water supply system in the city was recommended.

Objective

The objective of this study was to propose the improvement measures for the water supply system by evaluating the performance of the existing water supply system.

\section{Material and Methods}

\subsection{Description of the study area}

Adama City is located in Oromiya Regional State, Ethiopia, having a total area of $133.6 \mathrm{~km}^{2}$. The City is situated at a distance of $99 \mathrm{~km}$ South East of Addis Ababa and stretches between $8^{0} 33^{\prime} 35^{\prime \prime}$ to $8^{0} 36^{\prime} 36^{\prime \prime}$ latitude and $39^{0} 11^{\prime} 57^{\prime \prime}$ to $39^{0} 21^{\prime} 15^{\prime \prime}$ longitude. The highest and lowest altitude of the city ranges from 1600 - 1700 meters above mean sea level. 


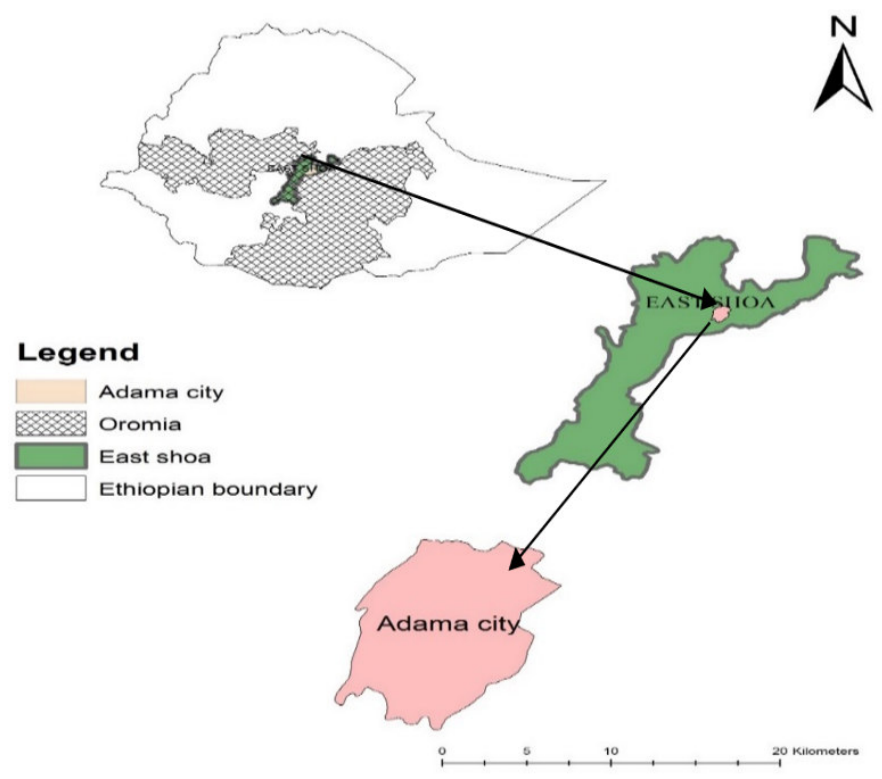

Figure 1. Location of the study area

\subsection{Performance indicators used in the study}

The IWA PIs has totally of 170 PIs, but as it was proposed by IWA manual only 21 to 26 PI are used for performance evaluation of WSS in developing countries (Alegre et al. 2000). Performance indicators of the IWA that selected for the evaluation of the water supply services were:

Water resources and financial performance indicators selected were, water resources availability, nonrevenue water by volume and average water charges for direct consumption.

Personnel performance indicators selected were, employees per connection, operation and maintenance personnel, water resources and catchment management personnel, abstraction and treatment personnel, transmission, storage and distribution personnel, water quality monitoring personnel, meter management personnel, employees per water produced.

Physical and operational performance indicators selected were, treatment plant utilization, treated water storage capacity, metered customers, water losses per connection, microbiological tests carried out, physicalchemical tests carried out, unmetered water.

Quality of service performance indicators selected were, population coverage, population coverage with service connections, population coverage with public pipes or standpipes, per capita water consumed in public taps and stand pipes, population per public tap or stand pipes, microbiological tests compliance, physical-chemical tests compliance.

Variable data's required to evaluate average water charges, water sales revenue from residential, industrial and other customers, exported water amount and period of assessment were collected. To evaluate non-revenue water by volume, non-revenue water and system input volume during the assessment period were collected. In order to analyze water resource availability system input volume during the assessment period, annual yield capacity of own sources and annual imported water allowance were collected from Adama water supply and sanitation enterprise (AWSSE).

Variable data's used to evaluate the performance of water losses per connection, water losses during the assessment period and number of service connections data were collected. To analyze unmetered water performance, system input volume during the assessment period and metered consumption data were collected. In order to analyze the microbiological and physical-chemical test carried out, Number of microbiological and physical-chemical tests of treated water carried out during the assessment period, number of microbiological and physical-chemical tests of treated water tests required by applicable standards or legislation during the assessment period were collected. to analyze treatment plant utilization performance, maximum daily volume of water treated in treatment plants during the assessment period and maximum daily capacity of the existing treatment plants data's were collected. To analyze the performance of treated water storage capacity, total capacity of treated water reservoirs and system input volume during the assessment period data's were collected.in order to analyze the performance of metered customers, number of direct and bulk customer meters and number of registered customers data's were collected from AWSSE.

Variable data's used to evaluate the performance of microbiological and physical-chemical tests compliance, 
number of microbiological and physical-chemical tests of treated water complying with the applicable standards or legislation during the assessment period and total number of microbiological and physical-chemical tests of treated water carried out during the assessment period data's were collected. To analyze the performance of population coverage, population coverage with service connection, population coverage with public tap or stand pipes and population per public tap or standpipe, resident population served by the water undertaking, total resident population, resident population served by the water undertaking through service connections, resident population served by the water undertaking through public taps or standpipes and number of public taps and standpipes data's were collected. To analyze the performance of per capita water consumed in public taps/standpipes, Sum, for all water points of the water consumption at the water point during the assessment period and resident population served by the water undertaking through public taps or standpipes during the assessment period data's were collected from AWSSE.

To evaluate the selected IWA personnel performance indicators of the water supply system the following variable data's, number of full time equivalent employees of the water undertaking, number of service connections, and number of full time equivalent employees working in the water resources and catchment management, water produced during the assessment period, number of full time equivalent employees working in planning, design, construction, operations and maintenance of the abstraction and treatment, and transmission, storage and distribution system, total mains length, number of full time equivalent employees working in water quality sampling and testing, total number of tests carried out by the undertaking laboratories during the assessment period, Number of full time equivalent employees working in meter management, total number of system and customer meters, Number of full time equivalent employees of the water undertaking, water produced during the assessment period, and number of full time equivalent employees of technical services working in operations and maintenance data's were collected from AWSSE.

Sample face to face household interviews using prepared questionnaires for the customers were carried out to collect information about customer's perception towards the water supply service, and water production and water consumption records were reviewed from annual report.

The data collection tools that used were, variable data checklist used to collect data of the existing water supply system from AWSSE and pre-prepared questionnaire to gather information from the city households. The field data collection consisting of interviews of the selected sample households from three sub cities that contain 8 kebeles of the city were selected, totally 300 households were selected.

The volume of water consumed was collected from bill record of the city water supply and sanitation enterprise to analyze the water supply coverage. The annual consumption data was converted to average daily per capita consumption using the number of population as shown in equation 1.

per capita water consumption (l/cap/day) $=\frac{\text { Annual consumption }(\mathrm{m} 3) * 1000 \mathrm{l} / \mathrm{m} 3}{\text { Population number of the kebele } * 365}$

To analyze level of connection in different Kebele of Adama City, the total numbers of connection per Kebele were converted to level of connection by using equation 2 .

Level of connection $=\frac{\text { Total number of connection by kebele }}{\text { (Number of population by kebele/Average family size of city) }}$

Total annual water produced and distributed to the distribution system and the water billed that is aggregated from the individual customer meter readings by finance department of the authority were used to quantify the total water loss of the city by using equation 3 .

Total water loss $(\%)=\frac{\text { Total water production(m3)-total water consumption(m3)(billed) }}{\text { Total water production }(\mathrm{m} 3)} * 100$----------------(Equation 3)

To analyze the selected performance indicators by SIGMAv 3.4 , all indicators selected have their own equation used to analyze them as shown in the following tables 1,2, 3 and 4.

Table 1. Equations used to evaluate the water resource and financial performance.

\begin{tabular}{|c|c|c|}
\hline Performance indicators & Units & Equations used to analyze the indicators \\
\hline Average water charges for direct consumption & $\left(\mathrm{US} \$ / \mathrm{m}^{3}\right)$ & $\begin{array}{l}\text { Water sales revenue from residential, industrial } \\
\text { and other customers (exported water excluded; } \\
\text { public water taxes excluded) / (total authorized- } \\
\text { exported water), during the assessment period }\end{array}$ \\
\hline Water resources availability & $(\%)$ & $\begin{array}{l}\text { (System input volume during the assessment } \\
\text { period } \times 365 / \text { assessment period)/ (annual yield } \\
\text { capacity of own resources }+ \text { annual imported } \\
\text { water allowance) } \times 100\end{array}$ \\
\hline
\end{tabular}


Table 2. Equations used to evaluate the physical and operational performance.

\begin{tabular}{|c|c|c|}
\hline Performance indicators & Units & Equations used to analyze the indicators \\
\hline Water losses per connection & $\left(\mathrm{m}^{3} /\right.$ connection/year) & $\begin{array}{l}\text { (Water losses during the assessment period } x 365 \\
/ \text { assessment period)/ number of service } \\
\text { connections }\end{array}$ \\
\hline Unmetered water & $(\%)$ & $\begin{array}{l}\text { (System input volume- metered consumption) / } \\
\text { system input volume during the assessment } \\
\text { period x } 100\end{array}$ \\
\hline Microbiological tests carried out & $(\%)$ & $\begin{array}{l}\text { Number of microbiological tests of treated water } \\
\text { carried out during the assessment period / number } \\
\text { microbiological tests of treated water tests } \\
\text { required by applicable standards or legislation } \\
\text { during the assessment period x } 100\end{array}$ \\
\hline Physical-chemical tests carried out & $(\%)$ & $\begin{array}{l}\text { Number of physical-chemical tests of treated } \\
\text { water carried out during the assessment period / } \\
\text { number of physical-chemical tests of treated } \\
\text { water required by applicable standards or } \\
\text { legislation during the assessment period x } 100\end{array}$ \\
\hline Treatment plant utilization & $(\%)$ & $\begin{array}{l}\text { Maximum daily volume of water treated in } \\
\text { treatment plants during the assessment period / } \\
\text { maximum daily capacity of the existing treatment } \\
\text { plants x } 100\end{array}$ \\
\hline Metered customers & (No./customer) & $\begin{array}{l}\text { Number of direct and bulk customer meters } \\
\text { number of registered customers }\end{array}$ \\
\hline Treated water storage capacity & (days) & $\begin{array}{l}\text { Total capacity of treated water reservoirs (private } \\
\text { storage tanks excluded) / system input volume } \\
\text { during the assessment period x assessment period. }\end{array}$ \\
\hline
\end{tabular}

Table 3. Equations used to evaluate the quality of service performance.

\begin{tabular}{|c|c|c|}
\hline Performance indicator & Units & Equations used to analyze the indicators \\
\hline $\begin{array}{l}\text { Microbiological } \\
\text { compliance }\end{array}$ & $(\%)$ & $\begin{array}{l}\text { Number of microbiological tests of treated water } \\
\text { complying with the applicable standards or legislation } \\
\text { during the assessment period / total number of } \\
\text { microbiological tests of treated water carried out during } \\
\text { the assessment period x } 100\end{array}$ \\
\hline $\begin{array}{l}\text { Physical-chemical } \\
\text { compliance }\end{array}$ & $(\%)$ & $\begin{array}{l}\text { Number of physical-chemical tests of treated water } \\
\text { complying with the applicable standards or legislation } \\
\text { during the assessment period / total number of physical- } \\
\text { chemical tests of treated water carried out during the } \\
\text { assessment period } x 100\end{array}$ \\
\hline Population coverage & $(\%)$ & $\begin{array}{l}\text { Resident population served by the water undertaking / } \\
\text { total resident population } \times 100\end{array}$ \\
\hline $\begin{array}{l}\text { population coverage with service } \\
\text { connections }\end{array}$ & $(\%)$ & $\begin{array}{l}\text { resident population served by the water undertaking } \\
\text { through service connections / total resident population } \mathrm{x} \\
100\end{array}$ \\
\hline $\begin{array}{l}\text { population coverage public taps } \\
\text { or standpipes }\end{array}$ & $(\%)$ & $\begin{array}{l}\text { Resident population served by the water undertaking } \\
\text { through public taps or standpipes / total resident } \\
\text { population } \mathrm{x} 100\end{array}$ \\
\hline $\begin{array}{l}\text { Per capita water consumed in } \\
\text { public taps and standpipes }\end{array}$ & (l/person/day) & $\begin{array}{l}\text { (Sum, for all water points, of the water consumption at the } \\
\text { water point during the assessment period } \mathrm{x} 1000 \text { ) / } \\
\text { resident population served by the water undertaking } \\
\text { through public taps or standpipes / assessment period }\end{array}$ \\
\hline $\begin{array}{l}\text { Population per public tap or } \\
\text { standpipe }\end{array}$ & (persons/ tap) & $\begin{array}{l}\text { Resident population served by the water undertaking } \\
\text { through public taps or standpipes / number of public taps } \\
\text { and standpipes }\end{array}$ \\
\hline
\end{tabular}


Table 4. Equations used to evaluate the personnel performance.

\begin{tabular}{|c|c|c|}
\hline Performance indicators & Units & Equations used to analyze the indicators \\
\hline Employees per connection & (No./1000connections) & $\begin{array}{l}\text { Number of full time equivalent employees of the } \\
\text { water undertaking / number of service } \\
\text { connections x } 1000\end{array}$ \\
\hline $\begin{array}{l}\text { Water resources and catchment } \\
\text { management personnel }\end{array}$ & $\left(\right.$ No. $/\left(10^{\wedge} 6 \mathrm{~m}^{3} /\right.$ year $\left.)\right)$ & $\begin{array}{l}\text { Number of full time equivalent employees } \\
\text { working in the water resources and catchment } \\
\text { management / (water produced during the } \\
\text { assessment period x } 365 / \text { assessment period) } x \\
10^{\wedge} 6\end{array}$ \\
\hline $\begin{array}{l}\text { Abstraction and treatment } \\
\text { personnel }\end{array}$ & $\left(\right.$ No. $/\left(10^{\wedge} 6 \mathrm{~m}^{3} /\right.$ year $\left.)\right)$ & $\begin{array}{l}\text { Number of full time equivalent employees } \\
\text { working in planning, design, construction, } \\
\text { operations and maintenance of the abstraction } \\
\text { and treatment / (water produced during the } \\
\text { assessment period } \times 365 \text { / assessment period) } x \\
10^{\wedge} 6\end{array}$ \\
\hline $\begin{array}{l}\text { Transmission, storage and } \\
\text { distribution personnel }\end{array}$ & (No./100km) & $\begin{array}{l}\text { Number of full time equivalent employees } \\
\text { working in planning, design, construction, } \\
\text { operations and maintenance of the transmission, } \\
\text { storage and distribution system / total mains } \\
\text { length } x 100\end{array}$ \\
\hline $\begin{array}{l}\text { Water quality monitoring } \\
\text { personnel }\end{array}$ & (10000tests/ & $\begin{array}{l}\text { Number of full time equivalent employees } \\
\text { working in water quality sampling and testing / } \\
\text { (total number of tests carried out by the } \\
\text { undertaking laboratories during the assessment } \\
\text { period x } 365 \text { / assessment period) x } 10000\end{array}$ \\
\hline Meter management personnel & (No./1000meters) & $\begin{array}{l}\text { Number of full time equivalent employees } \\
\text { working in meter management / total number of } \\
\text { system and customer meters } x 1000\end{array}$ \\
\hline Employees per water produced & $\left(\right.$ No. $/\left(10^{\wedge} 6 \mathrm{~m}^{3} /\right.$ year $\left.)\right)$ & $\begin{array}{l}\text { Number of full time equivalent employees of the } \\
\text { water undertaking / (water produced during the } \\
\text { assessment period } \times 365 / \text { assessment period) } \times \\
10^{\wedge} 6\end{array}$ \\
\hline $\begin{array}{l}\text { Operations \& maintenance } \\
\text { personnel }\end{array}$ & $(\%)$ & $\begin{array}{l}\text { Number of full time equivalent employees of } \\
\text { technical services working in operations \& } \\
\text { maintenance / number of full time equivalent } \\
\text { employees of the water undertaking x } 100\end{array}$ \\
\hline
\end{tabular}

\subsection{User perception analysis}

To analyze the House Holds (HHs) connected to the water distribution network which connected and not connected to the water distribution network, type of connection they used in terms of connection type, the quality of water for drinking delivered by the service provider to rank the water quality as satisfactory and unsatisfactory, type of container used to collect water, HHs collect rain water, rain water usage of households, reason for collecting rain water, HHs buy water from vendor/kiosk, reason for buying water from vendor, user perceive as major problems in relation to water services provision frequency were analyzed and to analyze the main source of drinking water the frequency of HHs uses of their main sources of drinking water were cross tabbed with sub-cities, by using SPSS software. 


\section{Result and Discussion}

3.1. Average daily per capita consumption of each Kebeles of Adama city were computed.

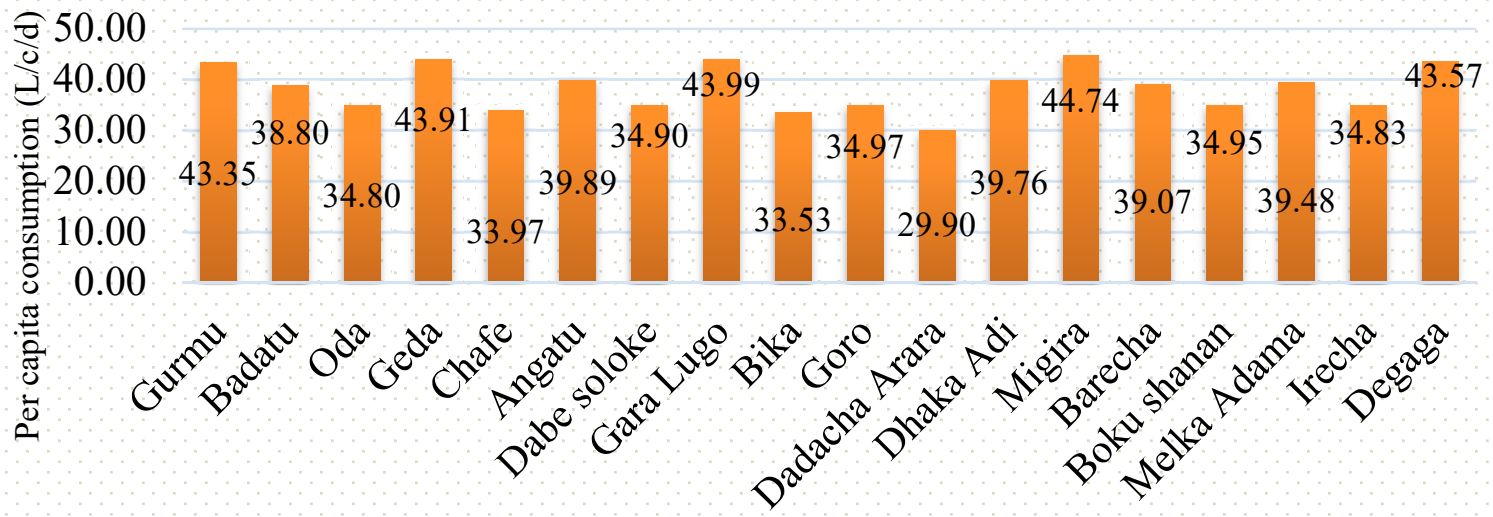

\section{Kebeles}

Figure 2. Per capita water consumption of kebeles in Adama city.

Average domestic water coverage of the city was $38.25 \mathrm{l} / \mathrm{p} / \mathrm{d}$. when it compared with other African cities Abidjan and Nairobi respectively 72 and 98 1/p/day (Collignon and Vézina 2000), Adama city Percapita water consumption was lower and need to improve.

\subsection{Level of water connection.}

Level of connection of the total households in different kebeles were calculated and it was on average $5.56 \%$ of the households were found to water use $<301 / \mathrm{c} / \mathrm{d}, 38.89 \%$ of the households $31-35 \mathrm{l} / \mathrm{c} / \mathrm{d}, 27.78 \%$ of the households $36-40 \mathrm{l} / \mathrm{c} / \mathrm{d}$ while the rest $27.78 \%$ of the households water use $>40 \mathrm{l} / \mathrm{c} / \mathrm{d}$.

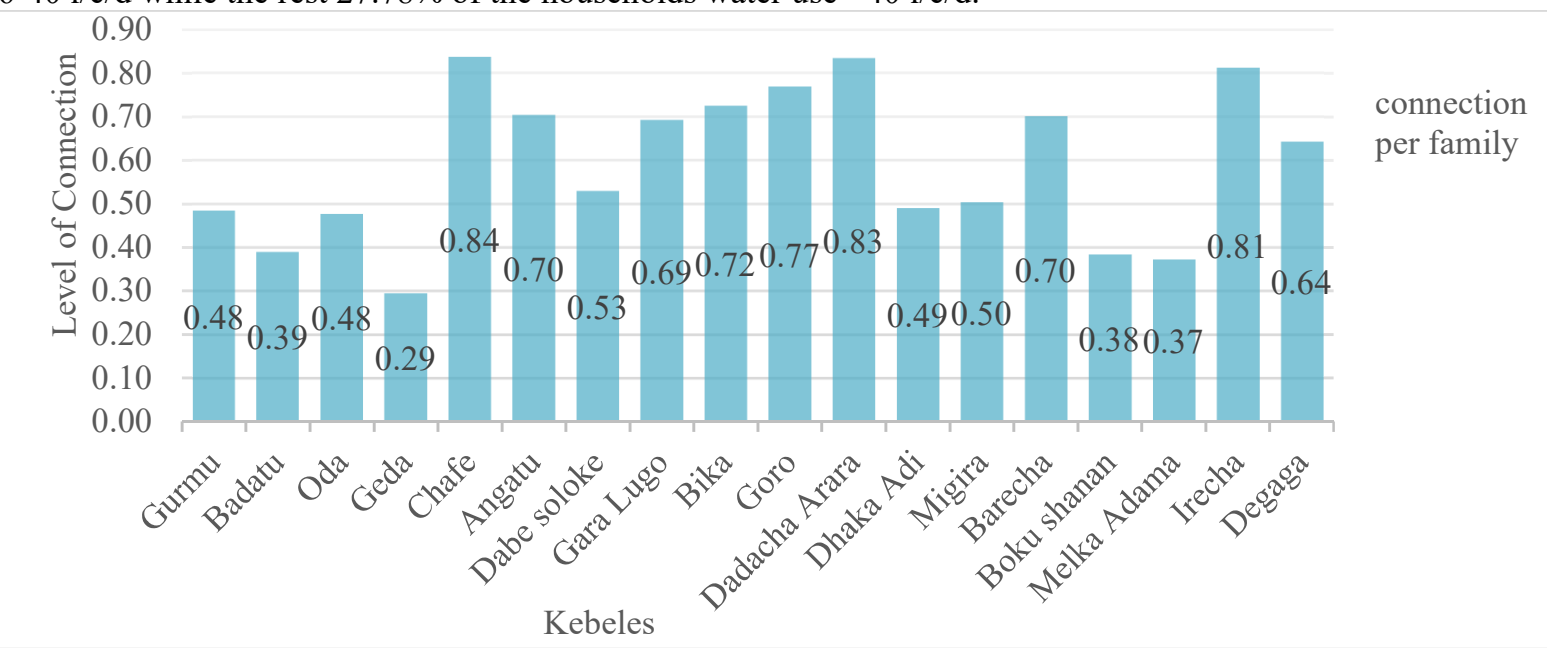

Figure 3. Level of water connection of Adama city.

Average level of water connection per family of the city was 0.59 . This implies that at average more than 1.7 families or seven persons were sharing one connection or water tap, In other words the average in-house or yard connection of the town was $59 \%$.

\subsection{Water loss of Adama city water supply system}

Total water loss amount of the city, annual water produced and distributed to the system and the water billed that was aggregated by the enterprise from the individual customers meter reading were shown in the following figure 4. 


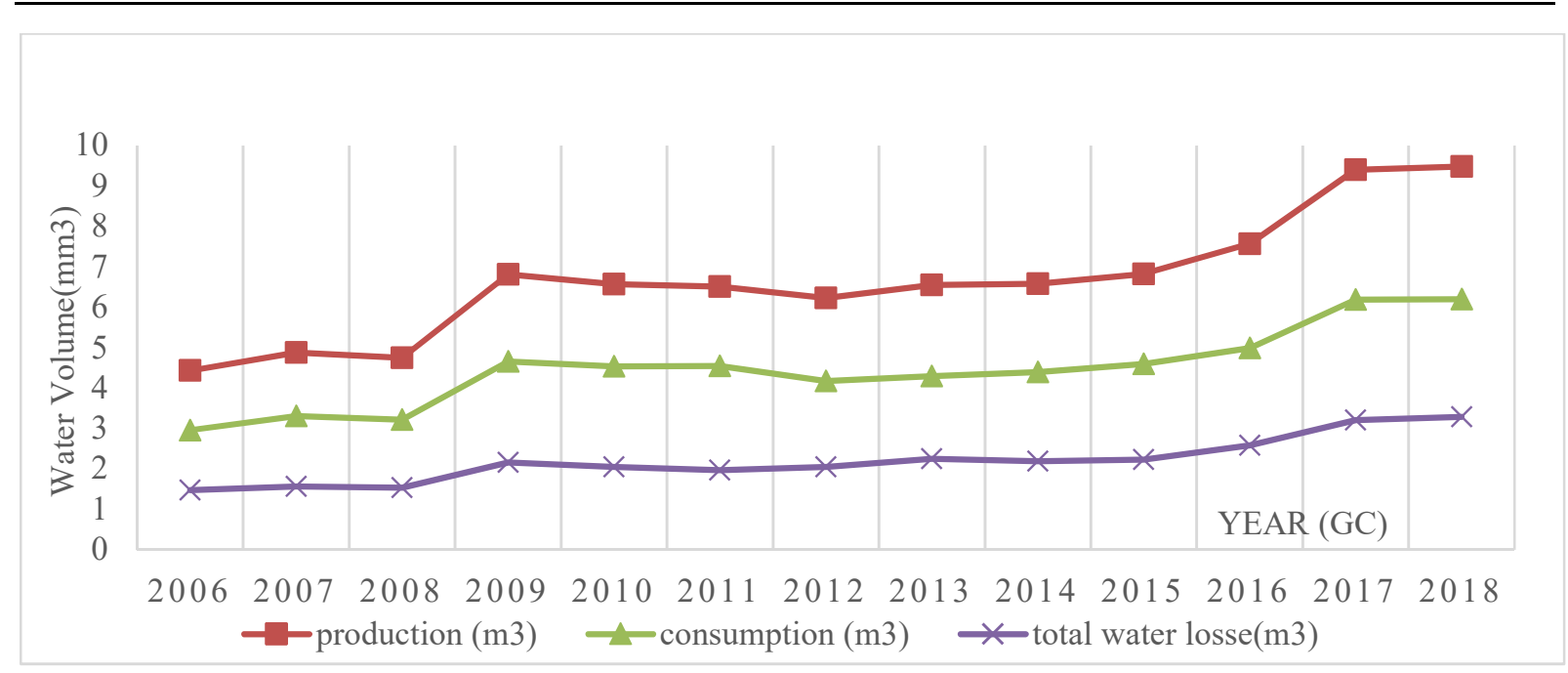

Figure 4. Annual water production, consumption and loss trends of Adama city.

Total water loss of the system in 2018 was $34.67 \%$ of the system input volume and is approximately $3288055 \mathrm{~m}^{3} /$ year, this amount of water loss was big when compared with the developed countries water loss in water supply system. Water loss in water supply systems ranges from $15 \%$ to $30 \%$ in the developed country but, elsewhere it is likely to range from 30\% to 60\% (Bridges and MacDonal 1994).

\subsection{Performance analysis by SIGMAv3.4}

Selected performance indicators were calculated by SIGMAv3.4 software and the performance situation of the water supply system was as follows:

Water resources availability ratio was $73.05 \%$. The value of this water resources performance indicator for Adama city water supply system was higher than that of selected areas of Addis Ababa 24.25\% (Bereket 2006). This indicates that the available water resources were used better. A higher value $(100 \%)$ of this parameter means that all the available resources are being used.

From financial performance indicators, Average water charges for direct consumption of Adama city water supply system was $0.27\left(\mathrm{US} \$ / \mathrm{m}^{3}\right)$.

From physical and operational performance indicators, treated water storage capacity of the water supply system was 0.63 /days. When this value compared to the value of selected areas of Addis Ababa 0.4/days (Bereket 2006), it shows better performance. Metered customer performance indicator result was 1 (Number/customer). This shows all the registered customers in the city were metered and it shows good performance. Treatment plant utilization was $54.2 \%$ which means $45.8 \%$ of the treating capacity of the treatment plant was not used due to different reasons, this shows lower performance. Water loss per connection ( $\mathrm{m}^{3} /$ connection /year) was 48.22 , when this value compared to the value for selected areas of Addis Ababa $119.92\left(\mathrm{~m}^{3} /\right.$ connection /year) (Bereket 2006), Adama city water supply system have better performance but not enough, $48.22 \mathrm{~m} 3 /$ connection/year mean too large for Ethiopia, because it pays or loses large cost for this amount of water. Unmetered water of the city water supply system was $34.02 \%$.

Microbiological tests carried out were $66.67 \%(\%)$ and physical chemical tests carried out were $55.56 \%(\%)$, When these values compared to the value of micro biological test carried out $96.96 \%$ and physical-chemical test carried out $100 \%$ for selected areas of Addis Ababa (Bereket 2006), Adama city performance was too low.

Performance indicators selected to analyze the quality of service of the water supply system were, Microbiological and physical chemical test compliance of the city water supply system were $100 \%$ and $100 \%$, when these values compared to the selected areas of Addis Ababa, i.e. micro biological and physical-chemical quality of supplied water $98.8 \%$ and $99.57 \%$ (Bereket 2006), Adama city water supply and sewerage enterprise performance was better.

Population coverage of the water supply system was $100 \%$, population coverage with service connections $86.71 \%$, population coverage with public taps or standpipes $13.29 \%$, Per capita water consumed in public taps and standpipes 16.03(1/person/day), but the per capita water consumed in public taps and standpipes were on average $16.03 \mathrm{l} / \mathrm{p} /$ day, this was below the world health organization standard $20 \mathrm{l} / \mathrm{p} / \mathrm{day}$, Population per public tap or standpipe 244.21(persons/tap). The result of operation and maintenance personnel was $4.41 \%$. This reflects that the operation and maintenance personnel of Adama city Water Supply \& Sewerage enterprise was very small as compared to selected area of Addis Ababa city 31.72\%. Employees per connection of the water supply system was 4.99 employees/1000 connections, when compared with value of selected areas of Addis Ababa i.e. 6.62 employees/1000connections (Bereket 2006), the value was still small in terms of employees/connection. Water resource and catchment management personnel was 0 , this was affect the water resource and catchment 
management of the water supply system. Abstraction and treatment personnel was 0.84 (No. / $\left(10^{\wedge} 6 \mathrm{~m}^{3} / \mathrm{year}^{2}\right)$. Transmission, storage and distribution personnel was $191.67(\mathrm{No} / 100 \mathrm{~km})$. Water quality monitoring personnel was 12857.14(No. / (10000tests/year)). Meter management personnel was 0.47 (No. /1000meters). Employees per water produced was 35.79 (No. / (10^6 $\mathrm{m}^{3} /$ year)).

\subsection{User perception analysis}

Households included in the analysis which connected to the water distribution network were $72 \%$ of the total households included in the analysis, $28 \%$ were not connected. $28 \% \mathrm{HHs}$ not connected to the water distribution network were use communal tap, out of $72 \%$ connected to the water distribution network $68.7 \%$ were used individual house connection and the left $3.3 \%$ were used shared yard connection.

Households included in the study were used three different types of primary water sources to fulfil their drinking water demand. These were, House connection, Public tap and Water vendors, of the total respondents $67 \%$ have individual connection, $20.33 \%$ use community tap and $12.67 \%$ buy water from vendors to fulfill their primary source, this result shows difference in the three sub cities, For instance, the households that get their primary water from the community tap were $8.7 \%$ in Boku sub-city, 6.7\% in Dabe sub-city and 5\% in Lugo sub-city and in Boku sub-city the respondent that get water from individual connection was larger as compared to other sub-cities.

The quality of water currently provided by the water provider as per the analysis $83.3 \% \mathrm{HHs}$ were rank it as satisfactory and $16.7 \%$ were rank it as unsatisfactory. Out of the total $300 \mathrm{HHs}$ selected $96.7 \%$ of them were use jerry can to collect water and the left $3.3 \% \mathrm{HHs}$ were use other vessels. The result of the analysis shows that no other water sources for the HHs without water supplied by water supply and sanitation enterprise of the city, and rain water collected during rainy season.

The alternative water source without water supplied by the city water supply and sanitation enterprise was rain water which they collect during rainy season. As the result shows, from the total households included in the study about 35\% were collect rain water, separately the percentage of households that collects rain water was $14.3 \%$ in Boku sub-city, $7.7 \%$ in Dabe sub-city and 13\% in Lugo sub-city this variation is occurred due to access to water line and living standard variation and type of the water source they use.

All the respondent whose collect rain water during rainy season, do not use it for drinking purpose, the main reason they did not used it for drinking was most of the time they collect the rain water in open material and they assume that piped water have more quality than that rain water collected in open space. Out of $35 \% \mathrm{HHs}$ whose collect rain water, $10.7 \%$ were used it for cleaning house, $4 \%$ for animal, $17 \%$ for laundry and $3.3 \%$ for other purposes, the reason of HHs whose collect rain water were $10 \%$ due to proximity, $21.3 \%$ due to cost and $3.3 \%$ due to inadequacy.

Out of the $300 \mathrm{HHs} 83.3 \%$ of them were buy water from vendor. Their reason to buy water from vendor $13.3 \%$ were adequacy, $63.3 \%$ better quality, $3.3 \%$ due to proximity and $3.3 \%$ due to lack of other sources.

User perceive in relation to the water supply service provision as a major problem were, Out of the total HHs included in the study, $23.3 \% \mathrm{HHs}$ were perceive that the cost of the water, $13.3 \%$ water shortage, $13.3 \%$ customer service, $23.3 \%$ water losses, $6.7 \%$ quality of the water and $16.7 \%$ other problem and $3.3 \% \mathrm{HHs}$ were perceive no problem.

\section{Conclusion}

Analysis of the selected performance indicators shows that among the IWA indicators of water supply service, water resource indicator shows better performance, operational indicators shows smaller performance, from quality of service indicators, average water tariff was better but need improvement, water resource indicators result shows better performance, from personnel indicators (employees/connection) and operation and maintenance personnel shows poor performance, and from physical indicators treated water storage shows better performance, metered customer good, and microbiological and chemical test carried out shows poor performance when compared with other water supply service in Ethiopia. And also the results were shows that, average Percapita water consumption of Adama city was $38.251 / \mathrm{c} / \mathrm{d}$ and the water loss was $34.67 \%$ of the system input volume.

Households included in the analysis which connected to the water distribution network were $72 \%$ of the total households. Out of the total households included in the study, of the total respondents $67 \%$ have individual connection $20.33 \%$ use community tap and $12.67 \%$ buy water from vendors. From the total households in the town about $35 \%$ were collect rain. The result of the analysis shows that no other water sources for the HHs without water supplied by the water supply and sanitation enterprise of the city and rain water collected during rainy season.

In order to improve the performance of the water supply services of the city, the following recommendations may be helpful. The city water supply and sanitation enterprise have to look seriously into water demand and water loss management, operational and maintenance personnel and personnel per connection performance should be improved for better operational performance, the performance of chemical and biological test carried out should be improved, and also the city water supply and sanitation enterprise should be improve the treatment plant utilization capacity for better usage of its capacity and also educating community is very important for better rain 
water collection strategy.

\section{Reference}

Alegre H., Hirner W., Babtista J. M. and Parena R. (2000) Performance indicators for water supply services, Manual of Best Practice Series, IWA publishing, London.

Ashley, R.M. and Hopkinson, P., (2002) Sewer systems and performance indicators into the 21 st Century, J. Urban Wat., 4.

Belindah. N (2011) Assessment of performance of urban water Supply in the city of Bulawayo, Zimbabwe.

Bereket, B. (2006) Evaluation of water supply systems in selected urban poor areas of Addis Ababa. MSc Thesis. UNESCO-IHE Institute for Water Education, Delft, the Netherlands.

Bridges G. and MacDonal M. (1994) Affordable Water Supply and Sanitation. Leakage Control- the neglected solution.

Cairn cross S, Carruthers I, Curtis D, Feachem R, Bradley D, Baldwin G (1980) Evaluation for village water supply planning, John Wiley and Sons, NewYork

Coelli T.J., Estache A., Perelman S., and Trujillo L. (2003) A Primer on Efficiency Measurement for Utilities and Transport Regulators, World Bank Publications.

Colligon B. and Vezina M. (2000) Independent water and sanitation providers in African cities: Full report of a ten-country study, IRC.

Comparative analyses, obstacles and recommandations." World Water Council. United Nations Centre for Human Settlements (UN-HABITAT), (2003) Water and Cities. Kyoto, Japan.

Faria A.L. and Alegre H. (1996) Paving the way to excellence in water supply systems. AQUA-J. Wat. Supply, Res. Technol., 45.

Linsley R. K., Franzini J. B., Freyberg D. L., \&Tchobanoglous G. (1992) McGraw-Hill Series in Water Resources and Environmental Engineering. New York.

Matos J.S.(1991) Aerobiosis and septicity in wastewater systems. PhD dissertation, Technical University of Lisbon. Mebet A. (2007) Assessment of water loss in water supply network: a case of Debre Markos town. MSc Thesis. Arba Minch University, Arba Minch, Ethiopia.

Trow S., \&Farley M. (2006) Developing a strategy for managing losses in water distribution networks', in Water Demand Management, eds D Butler \& FA Memon. IWA Publishing, London.

Wallingford HR. (2003) Handbook for the assessment of catchments water demand and use.

WHO (1983) Minimum evaluation procedure. The international drinking water supply and sanitation decade

WHO (2000) World Health Organization, Global water supply and sanitation assessment 2000 report.

WHO (1997) Guide line for drinking water quality second edition. Geneva: published by WHO. 